\title{
Cynodont teeth from the Carnian (Late Triassic) of northern Italy
}

\author{
Silvio Renesto and Spencer G. Lucas \\ Acta Palaeontologica Polonica 54 (2), 2009: 357-360 doi:http://dx.doi.org/10.4202/app.2008.0055
}

A jaw fragment with three teeth preserved, collected from the Gorno Formation (Carnian, Upper Triassic) of Lombardy (Italy) is described. The teeth are transversely elongated, three-cusped and bear anterior and posterior cingula. Their overall morphology supports their identification as postcanines of a gomphodont cynodont. The unique tooth morphology of the new specimen supports its attribution to a new genus and species, while at the same time precluding positive assignment to already known gomphodont families. There is a fairly small record of gomphodont cynodonts in Europe, so that the described specimen adds to the knowledge of the distribution and diversity of European gomphodonts and it also represents the first ever collected in Italy.

Silvio Renesto [silvio.renesto@uninsubria.it], Dipartimento di Biologia Strutturale e Funzionale, Università degli Studi dell'Insubria, via Dunant 3,

21100 Varese, Italy; Spencer G. Lucas [spencer.lucas@state.nm.us], NewMexico Museum of Natural History and Science, 1801 Mountain Road N.W. Albuquerque, New Mexico, 87104 USA.

This is an open-access article distributed under the terms of the Creative Commons Attribution License (for details please see creativecommons.org), which permits unrestricted use, distribution, and reproduction in any medium, provided the original author and source are credited. 